\title{
Basic Chemical Composition of Pinus spp. Sawdust from Five Regions of Mexico, for Bioenergetic Purposes
}

Jonathan Sergio Chávez-Rosales, ${ }^{a}$ Luis Fernando Pintor-Ibarra, ${ }^{a}$ Nicolás GonzálezOrtega, ${ }^{a}$ Rocio Orihuela-Equihua, ${ }^{a}$ Faustino Ruiz-Aquino, ${ }^{\mathrm{b}}$ Concepción Lujan-Álvarez, ${ }^{\mathrm{c}}$ and Jose Guadalupe Rutiaga-Quiñones ${ }^{\text {a,* }}$

The basic chemical composition and calorific value of 19 samples of pine sawdust from different forest industries located in five states of the Mexican Republic (Chihuahua, Michoacán, Durango, Oaxaca, and Nuevo León) were determined. The results obtained ranged as follows: total extractives $(6.1 \%$ to $23.4 \%)$, holocellulose $(60.1 \%$ to $70.4 \%)$, lignin $(20.5 \%$ to $25.8 \%$ ), ash $(0.27 \%$ to $0.95 \%), \mathrm{pH}$ (4.1 to 5.3$)$, and calorific value (20.1 $\mathrm{MJ} / \mathrm{kg}$ to $21.0 \mathrm{MJ} / \mathrm{kg}$ ). Except for the ash content, significant statistical differences were found according to the origin of the pine sawdust samples. Based on the results obtained, the sawdust biomass has the potential to obtain densified solid biofuels.

Keywords: Extractives; Holocellulose; Lignin; Ash; High heating value; Biomass

Contact information: a: Facultad de Ingeniería en Tecnología de la Madera, Edificio "D", Ciudad Universitaria, Universidad Michoacana de San Nicolás de Hidalgo, Av. Fco. J. Múgica S/N, Col. Felicitas del Rio, Morelia, Michoacán, C. P. 58040, México; b: Instituto de Estudios Ambientales, Universidad de la Sierra Juárez, Avenida Universidad S/N, Ixtlán de Juárez, Oaxaca, C.P. 68725 México; c: Facultad de Ciencias Agrícolas y Forestales, Universidad Autónoma de Chihuahua, Carretera Km 2.5 DeliciasRosales, Cd. Delicias, Chihuahua, C. P. 33000 México; *Corresponding author: rutiaga@umich.mx

\section{INTRODUCTION}

Within the conifers that grow in Mexico, the richest is the Pinus genus, with 40 species, of the 120 pine species that vegetate in the world (Gernandt and Pérez-de la Rosa 2014). The number of pine species that grow in the states of the Mexican Republic where this study was conducted is as follows: 14 species and 2 varieties in Chihuahua (LebgueKeleng et al. 2015), 15 species in Michoacán (Cué-Bär et al. 2006), 20 species in Durango (García and González 2003), 14 species and 2 varieties in Oaxaca (Del Castillo et al. 2006), and 15 species in Nuevo León (Estrada-Castillón et al. 2014).

In Mexico, the national timber forest production fluctuated during the 2008 to 2017 period, starting in 2008 with 6.3 million cubic meters $\log \left(\mathrm{m}^{3} \mathrm{l}\right)$ and ending with 9.0 million $\mathrm{m}^{3} \mathrm{l}$ in 2017. The main wood-producing states in 2017 were: Durango (28.4\%), Chihuahua (18.6\%), Oaxaca (8.1\%), Tabasco (6.7\%), and Michoacán (5.4\%). By genus or group of woods, timber forest production had the following distribution: Pinus spp. (70.9\%), Mexican pine "Oyamel" (2.5\%), other conifers (0.4\%), Quercus spp. (9.8\%), other hardwoods $(2.8 \%)$, precious woods $(0.2 \%)$, and tropical commons woods $(13.4 \%)$. On the production of coniferous wood, the states of Durango, Chihuahua, and Oaxaca stand out, representing $65.6 \%$ of national production. The total forest production of Pinus spp. wood was $6,386,758 \mathrm{~m}^{3} 1$ for that same 2017 year and had the following distribution: squared timber $(74.6 \%)$, cellulosic material $(10.8 \%)$, veneering and plywood $(7.1 \%)$, posts, piling and fencing $(0.4 \%)$, firewood $(3.5 \%)$, charcoal $\left(9.3 \times 10^{-3} \%\right)$, and tramway sleepers (cross- 
ties) (4.3\%). The Pinus spp. wood sawmill represented $84.2 \%$ of national production in 2017 (SEMARNAT 2020). This data reflects the important role of pine species in national timber production.

It is known that the wood transformation process generates lignocellulosic residues, which generally have no use (Zavala and Cortés 2000), but they are occasionally used locally (Correa-Méndez et al. 2014). It is important to focus efforts to use these wastes for energy purposes (Karinkanta et al. 2018) but given the variability in the chemical composition of the different biomasses (Werkelin et al. 2005; Spinelli et al. 2011), it is important to know their characteristics and properties to visualize domestic or industrial energy applications (Mitchual et al. 2014). Recently, data on granulometry, proximate analysis, and ultimate analysis have been reported for the biomass samples studied here (Rutiaga-Quiñones et al. 2020). Now, the goal of this work is to know the basic chemical composition of pine wood sawdust, derived from the primary processing of wood, to learn its potential for its possible use in the production of densified biofuels and also to generate reference data.

\section{EXPERIMENTAL}

\section{Lignocellulosic Material}

The collection of the lignocellulosic waste samples was carried out in different companies and forest ejidos (communal lands) in five states of the Mexican republic: Chihuahua (El largo, Agua azul, Grupo Gazo, and Multimaderas), Michoacán (Maderería Zamora, Maderas Preciosas Don Jesús, and Lázaro Cárdenas), Durango (Grupo Sezarik, Maderas y Tarimas Alba, Vencedores, La Cañita, and Pueblo Nuevo), Oaxaca (Unidad Comunal Forestal, Agropecuaria y de Servicios, Productora Comunal de Muebles Ixtlán, and Aserradero Mapsi), and Nuevo León (Maderas Los Pérez), and are the product of primary wood transformation of pine trees. It was not possible to separate the biomass samples by pine species, because in the forest exploitation the timber species are mixed and then transported to the sawmills. The collected sawdust was allowed to air dry (under shadow) and was subsequently ground and sieved to use the 40-mesh fraction for analysis (Mejía-Díaz and Rutiaga-Quiñones 2008).

\section{Chemical Analysis}

To determine the total extracts content a Soxhlet extraction was applied using solvents of increasing polarity (cyclohexane, acetone, and methanol), and finally hot water under reflux, $6 \mathrm{~h}$ in each case (Mejía-Díaz and Rutiaga-Quiñones 2008). Holocellulose (Wise et al. 1946), and lignin (Runkel and Wilke 1951) were determined in the material after successive extraction. In the original biomass, the ash content as per UNE-EN 14775 (2010) and the $\mathrm{pH}$ by the methodology of Sandermann and Rothkamm (1959) were determined.

\section{High Heating Value}

The high heating value of the lignocellulosic samples was calculated using the mathematical model based on the chemical composition (White 1987). 


\section{Statistical Analysis}

The chemical analyzes were performed in triplicate, and the mean value and standard deviation are reported.

Because only one sample was collected from the state of Nuevo León, the results obtained for this origin must be taken with reserve. However, to compare the results obtained by origin of the pine sawdust samples, an analysis of variance was applied at $95 \%$ statistical confidence, and the mean values were compared by means of the multiple range test with the least significant difference (LSD) method (Gutiérrez and de la Vara 2004). The results were analyzed using the Statgraphics Plus version 4.0 program (Statgraphics Technologies, Inc., The Plains, VA, USA).

\section{RESULTS AND DISCUSSION}

\section{Chemical Analysis}

Table 1 shows the list of samples in order of collection, and the results of the successive extraction processes applied. It was not within the scope of this work to carry out an analysis to know the chemical compounds of the extracts obtained. In general, the yield of solvent extraction had the following behavior: acetone > cyclohexane > hot water $>$ methanol. This could indicate that most of the extractable substances present in these lignocellulosic samples correspond to nonpolar compounds (Fengel and Wegener 1983; Hillis 1987), and to a lesser extent water soluble substances, whose components can be carbohydrates, proteins, and some inorganic salts (Fengel and Wegener 1983).

Table 1. Extractives Content in Biomass Samples by Successive Extraction (\%)

\begin{tabular}{|c|c|c|c|c|c|c|}
\hline Sample & Origin & $\begin{array}{l}\text { Cyclo- } \\
\text { hexane }\end{array}$ & Acetone & Methanol & $\begin{array}{l}\text { Hot } \\
\text { water }\end{array}$ & Total \\
\hline 1 & \multirow{4}{*}{$\begin{array}{c}\text { Chihua- } \\
\text { hua }\end{array}$} & $3.8 \pm 0.10$ & $5.3 \pm 0.03$ & $0.7 \pm 0.13$ & $2.0 \pm 0.06$ & $11.9 \pm 0.21$ \\
\hline 2 & & $2.1 \pm 0.15$ & $5.8 \pm 0.41$ & $0.9 \pm 0.19$ & $1.7 \pm 0.08$ & $10.6 \pm 0.27$ \\
\hline 3 & & $3.4 \pm 0.23$ & $5.3 \pm 0.66$ & $0.6 \pm 0.08$ & $2.1 \pm 0.18$ & $11.3 \pm 0.16$ \\
\hline 4 & & $3.4 \pm 0.18$ & $8.1 \pm 0.65$ & $0.6 \pm 0.04$ & $2.8 \pm 0.07$ & $14.8 \pm 0.48$ \\
\hline 5 & \multirow{5}{*}{$\begin{array}{l}\text { Micho- } \\
\text { acán }\end{array}$} & $1.6 \pm 0.19$ & $3.9 \pm 0.17$ & $0.5 \pm 0.05$ & $1.5 \pm 0.04$ & $7.4 \pm 0.08$ \\
\hline 6 & & 0.10 & $6.3 \pm 0.16$ & \pm 0.01 & 0.07 & $\begin{array}{c}13.2 \pm \\
0.02\end{array}$ \\
\hline 7 & & $2.5 \pm 0.09$ & $4.8 \pm 0.32$ & $0.9 \pm 0.16$ & $2.3 \pm 0.09$ & $10.6 \pm 0.04$ \\
\hline 8 & & $3.1 \pm 0.49$ & $4.3 \pm 0.31$ & $0.9 \pm 0.08$ & $2.1 \pm 0.01$ & $10.5 \pm 0.88$ \\
\hline 9 & & $2.4 \pm 0.10$ & $4.4 \pm 0.23$ & $0.8 \pm 0.05$ & $3.2 \pm 0.10$ & $10.8 \pm 0.08$ \\
\hline 10 & \multirow{6}{*}{$\begin{array}{l}\text { Duran- } \\
\text { go }\end{array}$} & $9.7 \pm 0.04$ & $8.7 \pm 0.03$ & $1.0 \pm 0.07$ & $4.0 \pm 0.10$ & $23.4 \pm 0.04$ \\
\hline 11 & & $6.7 \pm 0.38$ & $3.5 \pm 0.16$ & $1.2 \pm 0.05$ & $3.8 \pm 0.00$ & $15.1 \pm 0.16$ \\
\hline 12 & & $8.1 \pm 0.99$ & $4.7 \pm 0.34$ & $1.6 \pm 0.17$ & $2.6 \pm 0.39$ & $17.0 \pm 1.91$ \\
\hline 13 & & $4.2 \pm 0.36$ & $5.7 \pm 0.74$ & $0.7 \pm 0.33$ & $2.1 \pm 0.08$ & $12.7 \pm 0.12$ \\
\hline 14 & & $3.2 \pm 0.43$ & $7.3 \pm 0.30$ & $0.5 \pm 0.11$ & $1.4 \pm 0.08$ & $12.3 \pm 0.17$ \\
\hline 15 & & $2.1 \pm 0.10$ & $5.0 \pm 0.05$ & $0.9 \pm 0.06$ & $2.2 \pm 0.03$ & $10.3 \pm 0.12$ \\
\hline 16 & \multirow{3}{*}{ Oaxaca } & $2.0 \pm 0.06$ & $3.8 \pm 0.47$ & $0.8 \pm 0.01$ & $2.8 \pm 0.04$ & $9.4 \pm 0.51$ \\
\hline 17 & & $0.9 \pm 0.11$ & $2.6 \pm 0.59$ & $1.0 \pm 0.22$ & $1.6 \pm 0.30$ & $6.1 \pm 0.63$ \\
\hline 18 & & $2.1 \pm 0.04$ & $2.9 \pm 0.40$ & $0.9 \pm 0.05$ & $2.3 \pm 0.07$ & $8.2 \pm 0.32$ \\
\hline 19 & $\begin{array}{l}\text { Nuevo } \\
\text { León }\end{array}$ & $4.0 \pm 0.24$ & \pm 0.06 & \pm 0.31 & $1.9 \pm 0.19$ & 0.69 \\
\hline
\end{tabular}


In extracts obtained with non-polar solvents, fatty acids, resins, resin acids, terpenes, and stilbenes are often found in pine woods (Uprichard and Lloyd 1980; Fengel and Wegener 1983). In Pinus pseudostrobus wood, pinosylvin demethyl ether and pinosilvin dimethyl ether have been identified in petroleum ether extract and acetonic extract, respectively (Rutiaga-Quiñones 2001). In aqueous extracts of Pinus pseudostrobus wood, after successive extraction with organic solvents, small amounts of polysaccharides were detected from $0.5 \%$ to $2.4 \%$, while in wood the polysaccharide content varied from $67.2 \%$ to $67.8 \%$ (Rutiaga-Quiñones 2001). In general, the average total extractives content obtained by the applied extraction sequence (Table 1) is higher compared to reported results for some pine woods (7.6\% to 8.2\%) (Bernabé-Santiago et al. 2013), (3.5\% to $12.0 \%$ ) (Honorato-Salazar et al. 2016), and (6.6\% to 7.1\%) (Pintor-Ibarra et al. 2017). This variation could be attributed to the extraction method used, the type of wood, and it is known that there are variations even within the same tree (Hillis 1987).

Holocellulose values ranged from $60.1 \%$ to $70.4 \%$ (Table 2), and in general coincided with data reported for coniferous woods (67.0\% to 82.5\%) (Fengel and Wegener $1983)$ and especially for pine woods (64.0\% to 69.0\%) (Rowell et al. 2005), $(68.1 \%$ to $74.7 \%$ ) (Bernabé-Santiago et al. 2013), (66.7\% to 70.0\%) (Honorato-Salazar et al. 2016), and $(71.9 \%$ to $76.9 \%$ ) (Pintor-Ibarra et al. 2017). The authors' results were also consistent with the reported values (63.6\% to $67.4 \%$ ) for holocellulose content, obtained by delignification method for four species of Mexican pines from the cembroid subsection (Revilla-González 2011).

For lignin, the results ranged from $20.5 \%$ to $25.8 \%$ (Table 2). These values are in the lower range reported for conifers (25.6\% to 39.4\%) (Fengel and Wegener 1983) and are generally less than the results of previous research with pine woods (24.0\% to $28.5 \%$ ) (Bernabé-Santiago et al. 2013), (26.3\% to 28.6\%) (Honorato-Salazar et al. 2016), and (29.6\% to $32.5 \%$ ) (Pintor-Ibarra et al. 2017). This variation could be due to the analysis method used, the type of wood used in the analysis, the origin of the wood, since it is known that the variation in chemical composition is influenced by the growing conditions, geographical location, age of the trees, among others (Hon and Shiraishi 2001).

In relation to the amount of mineral substances, the results ranged from $0.27 \%$ to $0.95 \%$ (Table 2). In general, they coincided with data reported for pine woods (BernabéSantiago et al. 2013; Correa-Méndez et al. 2014; Pintor-Ibarra et al. 2017) and were also within the typical range for pine woods (0.1\% to 1.0\%) (UNE-EN 14961-1 2011). Based on these results, lignocellulosic residues could be used to make class A2 pellets, whose requirement is an ash content of less than $1.5 \%$, or to make class A1 pellets with materials whose ash content is below $0.7 \%$ (ISO 17225-2 2014).

The $\mathrm{pH}$ values range from 4.1 to 5.3 (Table 2), indicating that the $\mathrm{pH}$ of the samples is weakly acidic (Kollmann 1959). These values agree with previous reports for pine woods (Bernabé-Santiago et al. 2013; Pintor-Ibarra et al. 2017).

\section{Higher Heating Value}

The values obtained from the calorific value calculated using the mathematical model based on the chemical composition (White 1987) range from 20.1 to $21.0 \mathrm{MJ} / \mathrm{kg}$ (Table 2). These results are higher than those reported for the same sawdust samples (18.8 to $20.7 \mathrm{MJ} / \mathrm{kg}$ ), calculated using mathematical models based on ultimate analysis, proximal analysis, and the ash content (Rutiaga-Quiñones et al. 2020). They are also higher than range of typical variation reported for softwoods (18.5 to $19.8 \mathrm{MJ} / \mathrm{kg}$ ) (UNE-EN 14961-1 2011). The calorific value is related to the chemical components of wood, mainly with the 
content of lignin and extractives, in addition, in softwoods the content of resins increases the calorific value (White 1987).

Table 2. Holocellulose, Lignin, Ash, pH, and Calorific Value (HHV) in Biomass Samples

\begin{tabular}{|c|c|c|c|c|c|c|}
\hline Sample & Origin & $\begin{array}{l}\text { Holocel- } \\
\text { lulose (\%) }\end{array}$ & $\begin{array}{l}\text { Runkel Lignin } \\
(\%)\end{array}$ & $\begin{array}{l}\text { Ash } \\
(\%)\end{array}$ & $\mathrm{pH}$ & $\begin{array}{c}\mathrm{HHV} \\
(\mathrm{MJ} / \mathrm{kg})\end{array}$ \\
\hline 1 & \multirow{4}{*}{$\begin{array}{l}\text { Chihua- } \\
\text { hua }\end{array}$} & $64.5 \pm 0.58$ & $24.1 \pm 0.50$ & $0.47 \pm 0.01$ & $4.6 \pm 0.09$ & $20.5 \pm 0.05$ \\
\hline 2 & & $69.8 \pm 0.51$ & $20.9 \pm 0.46$ & $0.45 \pm 0.01$ & $4.1 \pm 0.03$ & $20.2 \pm 0.05$ \\
\hline 3 & & $67.0 \pm 0.74$ & $22.4 \pm 0.06$ & $0.73 \pm 0.03$ & $4.2 \pm 0.02$ & $20.3 \pm 0.02$ \\
\hline 4 & & $65.5 \pm 0.61$ & $23.6 \pm 0.06$ & $0.53 \pm 0.01$ & $4.2 \pm 0.01$ & $20.6 \pm 0.03$ \\
\hline 5 & \multirow{5}{*}{$\begin{array}{l}\text { Micho- } \\
\text { acán }\end{array}$} & $69.5 \pm 0.60$ & $23.5 \pm 0.12$ & $0.91 \pm 0.06$ & $4.8 \pm 0.20$ & $20.2 \pm 0.01$ \\
\hline 6 & & $67.8 \pm 0.19$ & $24.2 \pm 0.08$ & $0.50 \pm 0.01$ & $4.2 \pm 0.05$ & $20.6 \pm 0.004$ \\
\hline 7 & & $68.8 \pm 0.66$ & $25.5 \pm 0.49$ & $0.43 \pm 0.06$ & $4.2 \pm 0.01$ & $20.7 \pm 0.20$ \\
\hline 8 & & $66.4 \pm 0.14$ & $24.0 \pm 0.08$ & $0.64 \pm 0.02$ & $4.6 \pm 0.12$ & $20.4 \pm 0.07$ \\
\hline 9 & & $68.8 \pm 0.39$ & $24.1 \pm 0.79$ & $0.33 \pm 0.01$ & $5.3 \pm 0.24$ & $20.4 \pm 0.07$ \\
\hline 10 & \multirow{6}{*}{$\begin{array}{l}\text { Duran- } \\
\text { go }\end{array}$} & $60.4 \pm 0.87$ & $20.5 \pm 0.15$ & $0.58 \pm 0.06$ & $4.2 \pm 0.07$ & $21.0 \pm 0.01$ \\
\hline 11 & & $61.3 \pm 0.77$ & $24.4 \pm 0.37$ & $0.73 \pm 0.02$ & $4.3 \pm 0.06$ & $20.7 \pm 0.04$ \\
\hline 12 & & $60.1 \pm 0.79$ & $25.8 \pm 0.50$ & $0.55 \pm 0.07$ & $4.1 \pm 0.06$ & $20.9 \pm 0.09$ \\
\hline 13 & & $68.5 \pm 0.19$ & $22.9 \pm 0.53$ & $0.27 \pm 0.05$ & $4.1 \pm 0.23$ & $20.5 \pm 0.03$ \\
\hline 14 & & $68.7 \pm 0.31$ & $21.7 \pm 0.84$ & $0.75 \pm 0.01$ & $4.1 \pm 0.03$ & $20.3 \pm 0.05$ \\
\hline 15 & & $68.4 \pm 0.89$ & $22.8 \pm 0.21$ & $0.95 \pm 0.01$ & $4.2 \pm 0.01$ & $20.3 \pm 0.01$ \\
\hline 16 & \multirow{3}{*}{ Oaxaca } & $69.4 \pm 0.16$ & $23.6 \pm 0.01$ & $0.66 \pm 0.10$ & $4.1 \pm 0.01$ & $20.3 \pm 0.04$ \\
\hline 17 & & $70.4 \pm 0.70$ & $24.5 \pm 0.22$ & $0.34 \pm 0.03$ & $4.5 \pm 0.03$ & $20.1 \pm 0.03$ \\
\hline 18 & & $69.3 \pm 0.46$ & $24.7 \pm 0.32$ & $0.48 \pm 0.04$ & $4.6 \pm 0.04$ & $20.3 \pm 0.001$ \\
\hline 19 & $\begin{array}{l}\text { Nuevo } \\
\text { León }\end{array}$ & $67.2 \pm 0.62$ & $22.7 \pm 0.04$ & $0.50 \pm 0.11$ & $4.4 \pm 0.09$ & $20.5 \pm 0.05$ \\
\hline
\end{tabular}

Table 3 summarizes the results obtained in this study by region of collection of the lignocellulosic samples. Except for the values obtained for the ash content, significant statistical differences were found in the other results $(p<0.05)$. A higher extractives content is observed for the Durango samples, which is reflected in a higher calorific value (Table 3), the same pattern was observed for the samples from Oaxaca, where the least extractives amount tends to with a lower calorific value. Telmo et al. (2010), found that in 17 wood fuels, the calorific value was explained by $43.6 \%$ of the quantity of extractives and $56.4 \%$ of Klason lignin, emphasizing that softwoods tend to have a higher calorific value as a consequence of the extractives content.

Table 3. Summary of the Chemical Composition and Calorific Value of Biomass Samples by Collection Origin

\begin{tabular}{|c|c|c|c|c|c|c|}
\hline Origin & $\begin{array}{c}\text { Extractives } \\
(\%)\end{array}$ & $\begin{array}{c}\text { Holocellulose } \\
(\%)\end{array}$ & $\begin{array}{c}\text { Runkel } \\
\text { Lignin (\%) }\end{array}$ & $\begin{array}{c}\text { Ash } \\
(\%)\end{array}$ & $\mathrm{pH}$ & $\begin{array}{c}\mathrm{HHV} \\
(\mathrm{MJ} / \mathrm{kg})\end{array}$ \\
\hline Chihuahua & $12.1 \mathrm{a}$ & $66.7 \mathrm{a}$ & $22.9 \mathrm{a}$ & $0.55 \mathrm{a}$ & $4.3 \mathrm{a}$ & $20.4 \mathrm{a}$ \\
\hline Michoacán & $10.5 \mathrm{a}$ & $68.0 \mathrm{a}$ & $24.3 \mathrm{~b}$ & $0.56 \mathrm{a}$ & $4.6 \mathrm{~b}$ & $20.4 \mathrm{a}$ \\
\hline Durango & $15.1 \mathrm{~b}$ & $64.5 \mathrm{~b}$ & $23.0 \mathrm{a}$ & $0.64 \mathrm{a}$ & $4.2 \mathrm{a}$ & $20.6 \mathrm{~b}$ \\
\hline Oaxaca & $7.9 \mathrm{c}$ & $69.7 \mathrm{c}$ & $24.3 \mathrm{~b}$ & $0.49 \mathrm{a}$ & $4.4 \mathrm{~b}$ & $20.2 \mathrm{a}$ \\
\hline Nuevo León & $14.0 \mathrm{~b}$ & $67.2 \mathrm{a}$ & $22.7 \mathrm{a}$ & $0.64 \mathrm{a}$ & $4.4 \mathrm{~b}$ & $20.5 \mathrm{~b}$ \\
\hline Equal lowercase letters in the direction of the columns indicate statistical equality $(\mathrm{p}<0.05)$ \\
\hline
\end{tabular}




\section{CONCLUSIONS}

1. According to the solvents used, the total extractives content in biomass samples had the following behavior: acetone > cyclohexane $>$ hot water $>$ methanol.

2. The extractives concentration by origin of biomass samples had the following behavior: Durango $>$ Nuevo León > Chihuahua > Michoacán > Oaxaca.

3. By origin of the biomass samples, the amount of holocellulose from highest to lowest was as follows: Oaxaca > Michoacán > Nuevo León > Chihuahua > Durango.

4. The Runkel lignin concentration in the studied samples had the following behavior according to the origin: Oaxaca/Michoacán > Durango > Chihuahua > Nuevo León.

5. The ash concentration by origin of biomass samples had the following behavior: Durango/Nuevo León > Michoacán > Chihuahua > Oaxaca.

6. The $\mathrm{pH}$ value, from higher to lower acidity, varied in the biomass samples according to their origin as follows: Durango > Chihuahua > Nuevo León/Oaxaca > Michoacán.

7. The HHV by origin of biomass samples had the following behavior: Durango > Nuevo León > Chihuahua/Michoacán > Oaxaca.

8. Based on the results obtained, the pine sawdust has the potential to be used in the production of densified solid biofuels.

\section{ACKNOWLEDGMENTS}

The authors thank SENER-CONACYT for funding "Fondo de Sustentabilidad Energética", Grant No. FSE-SENER-2014-246911 "Clúster de Biocombustibles Sólidos para la generación térmica y eléctrica". The authors also wish to express gratitude to the companies and forest ejidos (communal lands) that donated the biomass samples.

\section{REFERENCES CITED}

Bernabé-Santiago, R., Ávila-Calderón, L. E. A., and Rutiaga Quiñones, J. G. (2013). "Componentes químicos de la madera de cinco especies de pino del municipio de Morelia, Michoacán [Chemical components of the wood of five pine species from the municipality of Morelia, Michoacán]," Madera Bosques 19(2), 21-35. DOI: 10.21829/myb.2013.192338

Correa-Méndez, F., Carrillo-Parra, A., Rutiaga-Quiñones, J. G., Márquez-Montesino, F., González-Rodríguez, H., Jurado-Ybarra, E., and Garza-Ocañas, F. (2014).

"Contenido de humedad y sustancias inorgánicas en subproductos maderables de pino para su uso en pélets y briquetas [Moisture and inorganic substance content in pine timber products for use in pellets and briquettes]," Rev. Chapingo Ser. Cie. 20(1), 7788. DOI: $10.5154 /$ r.rchscfa.2013.04.012

Cué-Bär, E. M., Villaseñor, J. L., Arredondo-Amezcua, L., Cornejo-Tenorio, G., and Ibarra-Manríquez, G. (2006). "La flora arbórea de Michoacán, México [The arboreal flora of Michoacán, Mexico]," B. Soc. Bot. Méx. 2006(78), 47-81. DOI: $10.17129 /$ botsci. 1721 
Del Castillo, R. F., Pérez-de la Rosa, J. A., Vargas-Amado, G., and Rivera-García, R. (2006). "Coníferas [Conifers]," in: Biodiversidad de Oaxaca, A. J. García-Mendoza, J. M. Ordóñez, and M. Briones-Salas (eds.), Instituto de Biología, UNAM, Fondo Oaxaqueño para la Conservación de la Naturaleza-World Wildlife Fund, México, D. F., México, pp. 141-158.

Estrada-Castillón, A. E., Villarreal-Quintanilla, J. Á., Salinas-Rodríguez, M. M., CantúAyala, C. M., González-Rodríguez, H., and Jiménez-Pérez, J. (2014). Coníferas de Nuevo León, México [Conifers of Nuevo León, Mexico], Universidad Autónoma de Nuevo León, México.

Fengel, D., and Wegener, G. (1983). Wood-Chemistry, Ultrastructure, Reactions, Walter de Gruyter, Berlin, Germany.

García-Arévalo, A., and González-Elizondo, M. S. (2003). Pináceas de Durango [Pinaceae from Durango], Instituto de Ecología, A. C., Xalapa, México.

Gernandt, D. S., and Pérez-de la Rosa, J. A. (2014). "Biodiversidad de Pinophyta (coníferas) en México [Biodiversity of Pinophyta (conifers) in Mexico]," Rev. Mex. Biodivers. 85(1), 126-133. DOI: 10.7550/rmb.32195

Gutiérrez-Pulido, H., and de la Vara-Salazar, R. (2004). Análisis y Diseño de Experimentos [Analysis and Design of Experiments], McGraw Hill, México, D. F., México.

Hillis, W. E. (1987). Heartwood and Tree Exudates, Springer-Verlag, Berlin Heidelberg, Germany.

Hon, D. N.-S., and Shiraishi, N. (2001). Wood and Cellulose Chemistry, Marcel Dekker, New York, USA.

Honorato-Salazar, J. A., Apolinar-Hidalgo, F., and Colotl-Hernández, G. (2016). "Composición lignocelulósica de Pinus ayacahuite Ehrenb. ex Schltdl., P. leiophylla Schlecht. \& Cham. y P. herrerae Martínez [Lignocellulosic composition of Pinus ayacahuite Ehrenb. ex Schltdl., P. leiophylla Schlecht. \& Cham. and P. herrerae Martínez]," Revista Mexicana de Ciencias Forestales 7(33), 47-56. DOI: 10.29298/rmcf.v7i34.82

ISO 17225-2 (2014). "Solid biofuels - Fuel specifications and classes," International Organization for Standardization, Geneva, Switzerland.

Karinkanta, P., Ämmälä, A., Illikainen, M., and Niinimäki, J. (2018). "Fine grinding of wood - Overview from wood breakage to applications," Biomass Bioenerg. 113(6), 31-44. DOI: 10.1016/j.biombioe.2018.03.007

Kollmann, F. (1959). Tecnología de la Madera y sus Aplicaciones [Wood Technology and its Applications], Ministerio de Agricultura - Instituto Forestal de Investigaciones y Experiencias, Madrid, Spain.

Lebgue-Keleng, T., Soto-Cruz, R., Quintana-Martínez, G., Quiñonez-Martínez, M., Balderrama-Castañeda, S., Melgoza-Castillo, A., Morales-Nieto, C., and CortesPalacios, L. (2015). "Árboles y arbustos templados de Chihuahua, México [Temperate trees and shrubs of Chihuahua, Mexico]," Medio Ambiente y Desarrollo Sustentable IX(1), 49-57.

Mejía-Díaz, L. A., and Rutiaga-Quiñones, J. G. (2008). "Chemical composition of Schinus molle L. wood and kraft pulping process," Rev. Mex. Ing. Quím. 7(2), 145149.

Mitchual, S. J., Frimpong-Mensah, K., and Darkwa, N. A. (2014). "Evaluation of fuel properties of six tropical hardwood timber species for briquettes," J. Sustain. Bioenergy Syst. 4(1), 1-9. DOI: 10.4236/jsbs.2014.41001 
Pintor-Ibarra, L. F., Carrillo-Parra, A., Herrera-Bucio, R., López-Albarrán, P., and Rutiaga-Quiñones, J. G. (2017). "Physical and chemical properties of timber byproducts from Pinus leiophylla, P. montezumae and P. pseudostrobus for a bioenergetic use," Wood Res. 62(6), 849-861.

Revilla-González, E. (2011). Química de la Madera de Cuatro Pinos Mexicanos de la Subsección Cembroides [Chemistry of the Wood of Four Mexican Pines of the Subsección Cembroides], Bachelor's Thesis, Universidad Autónoma Chapingo, Texcoco, México.

Rowell, R. M., Pettersen, R., Han, J. S., Rowell, J. S., and Tshabalala, M. A. (2005). "Cell wall chemistry," in: Handbook of Chemistry and Wood Composites, R. M. Rowell (ed.), Taylor \& Francis Group, Boca Raton, FL, USA, pp. 62-63.

Runkel, R., and Wilke, Y. K. D. (1951). "Zur Kenntnis des thermoplastischen Verhaltens von Holz [To know the thermoplastic behavior of wood]," Holz als Roh- und Werkstoff 9(7), 260-270. DOI: 10.1007/BF02617370

Rutiaga-Quiñones, J. G. (2001). Chemische und biologische Untersuchungen zum Verhalten dauerhafter Holzarten und ihrer Extrakte gegenüber holzabbauenden Pilzen [Chemical and biological investigations on the behavior of durable wood species and their extracts towards wood degrading fungi], Buchverlag Gräfelfing, Germany.

Rutiaga-Quiñones, J. G., Pintor-Ibarra, L. F., Orihuela-Equihua, R., González-Ortega, N., Ramírez-Ramírez, M. A., Carrillo-Parra, A., Carrillo-Ávila, N., Navarrete-García, M. A., Ruíz-Aquino, F., Rangel-Méndez, J. R., et al. (2020). "Characterization of Mexican waste biomass relative to energy generation," BioResources 15(4), 85298553. DOI: $10.15376 /$ biores. 15.4.8529-8553.

Sandermann, W., and Rothkamm, M. (1959). "Über die Bedeutung der pH-Werte von Handelsholzern und deren Bedeutung für die Praxis [About the importance of the $\mathrm{pH}$ values of commercial timber and their importance in practice]," Holz als Roh- und Werstoff 17(11), 433-440. DOI: 10.1007/BF02605386

SEMARNAT (2020). "Anuario estadístico de la producción forestal 2017 [Statistical Yearbook of Forest Production 2017]," Anuarios Estadísticos Forestales [Statistical Forestry Yearbooks], (https://www.gob.mx/semarnat/documentos/anuariosestadisticos-forestales), Accessed 16 July 2020.

Spinelli, R., Nati, C., Sozzi, L., Magagnotti, N., and Picchi, G. (2011). "Physical characterization of commercial woodchips on the Italian energy market," Fuel 90(6), 2198-2202. DOI: 10.1016/j.fuel.2011.02.011

Telmo, C., Lousada, J., and Moreira, N. (2010). "Proximate analysis, backwards stepwise regression between gross calorific value, ultimate and chemical analysis of wood," Bioresource Technol. 101(11), 3808-3815. DOI: 10.1016/j.biortech.2010.01.021

UNE-EN 14775 (2010). "Método para la determinación del contenido en cenizas [Method for the ash content determination]," Asociación Española de Normalización y Certificación (AENOR), Madrid, Spain.

UNE-EN 14961-1 (2011). "Especificaciones y clases de combustibles. Parte 1: Requisitos generales [Fuel specifications and classes. Part 1: General requirements]," Asociación Española de Normalización y Certificación (AENOR), Madrid, Spain.

Uprichard, J. M., and Lloyd, J. A. (1980). "Influence of tree age on the chemical composition of Radiata pine," New Zealand Journal of Forestry Science 10(3), 551557. 
Werkelin, J., Skrifvars, B.-J., and Hupa, M. (2005). "Ash-forming elements in four Scandinavian wood species. Part 1: Summer harvest," Biomass Bioenerg. 29(6), 451456. DOI: 10.1016/j.biombioe.2005.06.005

White, R. H. (1987). "Effect of lignin content and extractives on the higher heating value of Wood," Wood Fiber Sci. 19(4), 446-452.

Wise, L. E., Murphy, M., and D'Addieco, A. A. (1946). "Chlorite holocellulose, its fraction and bearing on summative wood analysis and on studies on hemicelluloses," Paper Trade J. 122(2), 35-43.

Zavala, D. Z., and Cortés, R. H. (2000). "Análisis del rendimiento y utilidad del proceso de aserrío de trocería de pino [Analysis of the performance and utility of the pine log sawing process]," Madera Bosques 6(2), 41-55. DOI: 10.21829/myb.2000.621374

Article submitted: October 16, 2020; Peer review completed: November 27, 2020;

Revised version received and accepted: December 6, 2020; Published: December 10, 2020.

DOI: $10.15376 /$ biores.16.1.816-824 